\begin{abstract}
Iranica
Abstracta Iranica Revue bibliographique pour le domaine irano-aryen

Volume 34-35-36 | 2017

Comptes rendus des publications de 2011-2013
\end{abstract}

\title{
Alexander Nagel. Color and gilding in Achaemenid architecture and sculpture
}

Astrid Nunn

\section{OpenEdition}

1 Journals

\section{Édition électronique}

URL : http://journals.openedition.org/abstractairanica/41682

DOI : 10.4000/abstractairanica.41682

ISSN : 1961-960X

Éditeur :

CNRS (UMR 7528 Mondes iraniens et indiens), Éditions de l'IFRI

\section{Référence électronique}

Astrid Nunn, «Alexander Nagel. Color and gilding in Achaemenid architecture and sculpture », Abstracta Iranica [En ligne], Volume 34-35-36 | 2017, document 83, mis en ligne le 15 juillet 2016, consulté le 28 septembre 2020. URL : http://journals.openedition.org/abstractairanica/41682 ; DOI : https://doi.org/ 10.4000/abstractairanica.41682

Ce document a été généré automatiquement le 28 septembre 2020.

Tous droits réservés 


\title{
Alexander Nagel. Color and gilding in Achaemenid architecture and sculpture
}

\author{
Astrid Nunn
}

\section{RÉFÉRENCE}

Alexander Nagel. "Color and gilding in Achaemenid architecture and sculpture », in :

D.T. Potts, éd. The Oxford Handbook of Ancient Iran. New York, Oxford University Press, 2013, p. 596-621.

1 La (re-)découverte de la polychromie antique reste un des domaines les plus fascinants de la recherche archéologique actuelle. Il y a encore quelques années ce thème n'aurait pas eu droit à son propre chapitre dans un ouvrage de synthèse. L'A. reconstitue depuis environ 2000 et grâce à des techniques sophistiquées les couleurs des reliefs et des chapiteaux tauriformes de Persépolis. En premier lieu, il résume et systématise ce que d'anciens voyageurs et fouilleurs avaient vu en pigments verts, rouges et bleus. Le travail mené sur la façade de la tombe de Darius I à Naqš-e Rostam a révélé du bleu égyptien dans toutes les inscriptions et sur le socle du trône ainsi que du rouge sur les denticules de l'entablure. Des pigments rouges, bleus et verts ont été identifiés sur le filet du registre. Les chapiteaux tauriformes étaient bleus. Ce nouveau tableau indique un système de références croisées entre pierres précieuses et peinture. Le bleu des chapiteaux imitait le lapis lazuli, certaines peintures sur les reliefs faisaient référence aux pierres précieuses et les couleurs qui recouvraient les colonnes de bois étaient une allusion à la pierre. Quant à la vraie couleur de la pierre, elle restait invisible ! 


\section{AUTEURS}

\section{ASTRID NUNN}

Université de Munich 